\title{
MENINGKATKAN MOTIVASI BELAJAR PESERTA DIDIK DENGAN BIMBINGAN KLASIKAL METODE PROBLEM BASED LEARNING SMP NEGERI 1 ASTAMBUL
}

\author{
Akhmad Riyadi \\ SMP Negeri 1 Astambul
}

\begin{abstract}
ABSTRAK
Peserta didik hendaknya memiliki kemampuan motivasi belajar yang tinggi sehingga senantiasa memiliki dorongan dan semangat dalam mengikuti proses belajar dan mencapai tujuan pembelajaran yang diharapkan. Layanan bimbingan klasikal melalui metode problem based learning bertujuan untuk meningkatkan motivasi dalam mengikuti pembelajaran. Partisipan dalam kegiatan ini adalah peserta didik kelas VIII C SMP Negeri 1 Astambul dengan jumlah 24 orang. Kegiatan layanan dilakukan melalui tiga tahap yakni tahap awal, tahap inti, dan tahap penutup.
\end{abstract}

Kata Kunci: motivasi belajar, bimbingan klasikal, problem based learning

\section{PENDAHULUAN}

Belajar adalah proses interaksi antara individu dengan sumber belajar yang menghasilkan suatu perubahan tingkah laku. Slameto (2003: 2). Pada dasarnya tujuan utama dari kegiatan belajar mengajar adalah agar peserta didik menguasai materi pelajaran sesuai dengan kompetensi yang telah ditetapkan.

Namun ketika dalam kegiatan belajar mengajar, banyak peserta didik yang tidak termotivasi dalam belajarnya. Peserta didik menganggap belajar sebagai beban dan merasa tidak semangat dalam belajar. Kegiatan belajar mengajar di kelas tak dapat dipisahkan dari sosok guru. Peranan guru sebagai fasilitator dan juga motivator, menjadi hal yang sangat penting dalam berlangsungnya proses pembelajaran yang efektif. Dan proses belajar mengajar yang efektif itu sendiri memerlukan motivasi belajar dari peserta didik itu sendiri.

Motivasi belajar adalah seluruh daya penggerak di dalam diri peserta didik yang menimbulkan kegiatan belajar yang menjamin kelangsungan dari kegiatan belajar yang memberikan arah pada kegiatan belajar sehingga tujuan yang dikehendaki oleh subjek belajar itu dapat dicapai. Sardiman A. M (2007: 75)

Pada saat kegiatan belajar mengajar, peserta didik seringkali tidak memiliki semangat. Hal ini karena mereka merasa tidak adanya kegiatan yang menarik dalam belajar, tidak ada keinginan untuk berhasil, tidak merasa adanya kebutuhan dalam belajar, tidak memiliki cita-cita di masa depan dan tidak adanya lingkungan belajar yang kondusif, sehingga memungkinkan mereka dapat belajar dengan baik.

Usaha untuk meningkatkan motivasi belajar peserta didik dapat dilakukan melalui bimbingan klasikal. Bimbingan klasikal adalah salah satu pelayanan dasar bimbingan yang dirancang menuntut konselor untuk melakuka kontak langsung dengan para peserta didik dikelas secara terjadwal, konselor memberikan pelayanan bimbingan ini kepada peserta didik. Melalui bimbingan klasikal maka diharapkan peserta didik memperoleh pemahaman tentang pentingnya motivasi belajar. Selain itu, melalui bimbingan klasikal, peserta didik juga dapat meningkatkan motivasi belajar mereka yang nantinya akan berimbaspada setiap proses belajar yang mereka lakukan. 


\section{METODE}

Pada metode penelitian ini peneliti menggunakan penelitian pendekatan deskriptif yang mana dengan melihat, merasakan mengamati dan sebagainya suatu objek dan subjek terhadap responden berjumlah 10 orang.

Menurut Machfudz (dalam Rizqiyah, 2016) Penelitian deskriptif adalah penelitian yang bermaksud untuk membuat deskripsi, gambaran atau lukisan secara sistematis, faktual dan akurat mengenai fakta-fakta, sifat-sifat serta hubungan antar fenomena yang diselidiki. maka peneliti menggunakan bahwa penelitian atau pendekatan yang akan digunakan dalam penelitian ini yaitu pendekatan deskriptif kulitatif, karena seperti yang dijelaskan di atas bahwa data deskriptif adalah data yang dapat diamati.

Metode pengambilan data dalam penelitian ini adalah observasi, wawancara dan dokumentasi. Dalam metode observasi yang digunakan adalah observasi non partisipan, yaitu dalam proses kegiatan mengadakan pengamatan langsung di SMP Negeri 1 Astambul, namun penulis tidak secara langsung berpartisipasi atau ikut serta dalam kegiatan (Hadari Nawawi, 2000). Dalam metode wawancara, jenis wawancara digunakan adalah bebas terpimpin, pedoman wawancara yang hanya berupa garis besarnya saja tentang hal-hal yang ditanyakan dan sesuai dengan data yang diteliti (Ahmad Tanzeh, 2011).

Dalam metode dokumentasi, digunakan untuk mendapatkan sejumlah data, yaitu tentang letak geografis, sejarah berdiri dan perkembangan sekolah, visi-misi dan tujuan sekolah, struktur organisasi, sarana dan prasarana, keadaan dan kondisi guru dan peserta didik, serta data terkait dengan peran guru BK dalam penyesuaian diri peserta didik dengan lingkungan sekolah baru.

Data yang telah terkumpul pada penelitian ini akan dianalisis sesuai dengan tahapan menurut Miles \& Huberman (Sugiono, 2016), yaitu reduksi data, penyajian data dan penarikan Kesimpulan.

\section{HASIL DAN PEMBAHASAN}

Peneliti menggunakan analisis data deskriptif untuk mencari tingkat persentase motivasi belajar peserta didik berdasarkan skala motivasi belajar. Peneliti menggunakan analisis deskriptif yaitu dengan menjelaskan hasil perhitungan skor hasil Penilaian Segera (laiseg). Skala motivasi belajar menggunakan skor 0 sampai 2. Berdasarkan perhitungan di atas, maka kriteria penilaian tingkat peningkatan motivasi belajar yang digunakan peneliti melalui interval perhitungan. Untuk kriteria peserta didik dari motivasi belajar Sangat Rendah mulai 40\% - 46\%, kriteria Rendah $47 \%$ - 53\%, kriteria Sedang 54\% - 60\%, kriteria Tinggi $61 \%-67 \%$, dan untuk kriteria Sangat Tinggi 68\% - 100\%.

Jumlah total peserta didik terdiri dari 10 orang, yang mana sejumlah 5 orang mendapatkan skor Sangat Tinggi (50\%). Peserta didik yang berjumlah 3 orang mendapatkan skor Tinggi (30\%), dan tersisa 2 orang yang mendapatkan skor sedang (20\%).Namun secara keseluruhan peserta didik menunjukkan tingkat motivasi yang Sangat Tinggi. Hal ini menunjukkan proses pemberian layanan secara klasikal melalui metode Problem based learning efektif dilakukan untuk meningkatkan motivasi peserta didik.

Setiap peserta didik dituntut untuk bekerja dalam kelompok melalui rancangan tertentu yang sudah dipersiapkan untuk menyampaikan hasil diskusinya agar membuat setiap peserta didik menjadi aktif dan fokus untuk melakukan proses diskusi. Langkah tersebut diambil karena dengan menggunakan metode pembelajaran problem based learning, peserta didik akan termotivasi untuk dapat mengungkapkan ide di dalam wadah kelompok sendiri maupun kelompok lainnya. Pada akhirnya dari proses diskusi, motivasi peserta didik dapat 
menjadi lebih meningkat pada proses pembelajaran. Hasil kegiatan menunjukkan motivasi dalam berdiskusi membahas topik yang didapatkan sangat efektif dilakukan. Hal ini ditunjukkan dengan cara pengentasan masalah yang dapat peserta didik tuangkan melalui diskusi dan curah pendapat.

Pada Saat diskusi, masing-masing anggota kelompok menunjuk salah satu perwakilan untuk menyampaikan hasil diskusi di depan kelas. Ketika tahap inti akan berakhir, peneliti kembali menjelaskan topik yang dibahas masing-masing kelompok, agar semakin menambah pemahaman mereka untuk mengembangkan motivasi saat belajar ketika selesai dari kegiatan ini. Selanjutnya peneliti mengajak peserta didik untuk menyimak PPT dan menganalisa apa yang terjadi dari permasalahan tersebut. Beberapa peserta didik kemudian mengangkat tangan dan menjelaskan isi dari PPT tersebut yang dikaitkan ke semua topik kegiatan yang sudah dilakukan. Slide PPT yang diberikan memberikan pemahaman kepada peserta didik tentang pentingnya motivasi belajar.

Ketika peserta didik memiliki motivasi belajar yang tinggi, itu akan sangat berpengaruh pada setiap tahap proses belajar mereka untuk mendapatkan hasil yang baik, sebaliknya ketika peserta didik memiliki motivasi belajar yang rendah, itu juga akan sangat berpengaruh pada setiap tahap proses belajar mereka, sehingga peserta didik kemungkinan sulit untuk mendapatkan hasil yang baik yang diharapkan. Semuanya tergantung kepada peserta didik dengan melihat faktor-faktor yang ada dalam diri peserta didik, serta peserta didik perlu memiliki gaya belajar yang baik untuk membantu motivasi belajarnya.

Setelah peneliti menyimpulkan kegiatan yang telah dilakukan, peneliti memberikan evaluasi ke peserta didik dengan harapan melihat sejauh mana proses kegiatan dari layanan yang diberikan apakah membantu peserta didik memahami dan mengembangkan motivasi belajarnya. Tentunya dari kegiatan ini, guru kembali memberikan motivasi dan penguatan kepada peserta didik untuk mendorong peserta didik mengembangkan motivasi dalam mengikuti pelajaran yang sedang dihadapi baik di rumah maupun di sekolah. Guru mengakhiri kegiatan dengan memberikan salam dan ucapan terima kasih kepada peserta didik.

\section{KESIMPULAN}

Berdasarkan hasil kegiatan yang telah dilakukan menunjukkan kegiatan yang dilalukan dapat meningkatkan motivasi belajar peserta didik kelas VIII C di SMPN 1 Astambul. Peserta didik sering kali merasa bosan dan tidak semangat saat guru menyampaikan materi pelajaran. Sudah pasti, guru harus memliki pengetahuan bagaimana cara mengatasi kasus seperti itu. Ketika peserta didik bosan dan tidak semangat dalam mengikuti pelajaran, itu merupakan salah satu ciri bahwa peserta didik telah kehilangan motivasi belajarnya. Maka dari itu guru sebaiknya melakukan upaya untuk meningkatkan motivasi peserta didiknya, agar peserta didik dapat mengikuti pelajaran dengan baik dan dengan mudah menangkap materi yang diberikan.

\section{DAFTAR PUSTAKA}

ABKIN, Direktorat Jenderal Peningkatan Mutu Pendidikan dan Tenaga Kependidikan Departemen Pendidikan Nasional. (2007). Penataan pendidikan profesional konselor dan layanan bimbingan dan konseling dalam jalur pendidikan formal. Jakarta: Departemen Pendidikan Nasional.

A.M, Sardiman. 2007. Interaksi dan Motivasi Belajar. Jakarta: Rineka Cipta. 
Jurnal Inovasi BK,Volume 2, Nomor 1 Juni 2020

Barbara K. Given. 2007. Brain-Based Teaching. Bandung: PT Mizan Pustaka.

Dimyati, dan Mudjiono. 2006. Belajar dan Pembelajaran. Jakarta: Rineka Cipta.

Masni, H. 2015. Strategi Meningkatkan Motivasi Belajar Peserta Didik. Dikdaya.

Nur, Hidayatun. 2020. Motivasi Belajar Peserta Didik Mata Kuliah Tulisan Arab Melayu Dengan Menggunakan Cara Online. Riau : Prodi Pendidikan Bahasa Indonesia Universitas Islam Riau. https://educhild.ejournal.unri.ac.id/in dex.php/JPSBE/article/download/76 97/pdf

Uno, H. 2011. Teori Motivasi dan Pengukurannya. Jakarta: PT Bumi Aksara.

Winkel.WS 2005. Bimbingan dan Konseling di Institusi Pendidikan. Yogyakarta: Media Abadi. 